\title{
Challenges and Opportunities of Investment to the People of Sebeta Town, Oromia Regional State
}

\author{
Kebede Lemu Bekelcha \\ Lecturer at Bule Hora University
}

\begin{abstract}
This study deals with the challenges and opportunities of investment to the people of Sebeta town. Currently, countries throughout the world are intensifying investment activities in African countries. Ethiopia is one of them. The developing countries are in need of heighted investment activities for employment and income generation. Despite its positive impact pertaining to employment, investment also brings challenges to the community. The focus of this study is to investigate the challenges and opportunities of investment to the people of Sebeta town of Oromia Regional State. To achieve this objective, both primary and secondary data was used. For this purpose, informants selected from the displaced people, government officials, workers of different investment types and selected residents of the town were participants of focus group discussions, interview (semi-structured), observation and case study. In such away, 141 individuals were directly involved in this study. In anthropological studies, analysis is an instrument to extract meanings from the information obtained during the field work. In such a manner, data were presented in a qualitative type. The result of the study showed that local communities lost their land, which used to serve for farming and residential purposes with inadequate cash compensation, rivers were contaminated by waste released from companies, labor exploitation and number of workers in several companies were disabled, and instability in the town. Investment also brought several opportunities for local people as source of income, skills and technology transfer. Local communities used daily labor, self-employment informal sector to sustain their livelihood. Based on the findings of the research, some alternatives were forwarded that could solve the problem and capitalize the opportunities available. In this regards, implementing proclamations and regulations of the country, prioritizing people in decision making and reconstructing the livelihoods of displaced household's need emphasis by the concerned bodies.
\end{abstract}

Keywords: Investment; Challenges; Opportunities; Livelihood; Sebeta.

DOI: $10.7176 /$ RHSS/9-17-05

Publication date:September $30^{\text {th }} 2019$

\section{Introduction}

Flow of investments in developing countries may seem to be a fairly recent phenomenon. However, such operations have a long history in many countries. During colonial times, foreign powers established large plantations in Asia, Africa, and Latin America. They use local populations for labor and host country populations benefited little (Vhugen, 2012). Since 2008, what appeared as a new boost of neo-colonial resource exploitation in Africa by investors from more-developed countries, led to heated debates on land grabbing in the media, and created concern among civil society and international organizations, as well as development agencies and researchers (Kaarhus et al, 2010).

Scholars have long debated the impact of investment on the economies of developing countries. Many argue that investment is beneficial for the receiving country (host) which leads to infrastructure expansion, creates more jobs and skill, increases the domestic food supply, increases access to market and foreign exchange reserve and these contributes to "sustained" and "broad based development" (World Bank, 2010). But Andersson and Robertson signaled the dangers associated with investments in Africa such as, natural resource degradation, loss of indigenous practices and increasing food insecurity and conflict (Andersen \& Robertson, 2010), because, government authorities give away land to investors without consulting land holders or their communities (Mesfin, 2013). Hence, the views are mixed whether investment brings meaningful benefit to the local community or not. However, the expropriation of millions of hectares of arable land by foreign investors took place in developing countries which caused development agencies and researchers to be concerned about it due to its environmental, political and socio-economic impact on the host countries and contribution to improve the development aspects of the host countries (Desalegn, 2011). Currently, worldwide countries are intensifying investment activities in Africa and most African countries attempted to create enabling environment in recent decades. Like other African countries, Ethiopia designed own investment policy, in order to attract investors to invest in Ethiopia (Dejene, 2014). Ethiopia has received foreign and domestic investors, and blamed for investments not carried out in a manner that safeguards the environmental, social, cultural, and food needs of local people.

In the course of reviewing findings of some previously conducted studies, it has been indicated that many recent investments have entailed the dispossession and displacement of households, damaging their local livelihoods, food security and access to key resources. For instance, plantations in the lower Omo River and Lake Turkana have pushed out local inhabitants (Hodbod et al, 2019). Such investments entail negative impacts 
particularly on the local communities, who see their livelihood hampered by land acquisitions.

Thousands of people have been displaced from their ancestral land due to investments in Ethiopia and have failed to feed their families afterwards (Oakland Institute, 2011). This is the forcing of communities and individuals out of their home, often also their homelands, for the purposes of economic development (UNHD, 1990). Such failure of investment created lose-lose-lose situation for investors, host countries and local communities.

However, employment is one key factor for conveying the effects of investments and local people often identify jobs as the most important and immediate benefit of investments. Investors often claim a commitment to bring technology, create jobs and an adequate infrastructure in the recipient country. In general, beside its opportunities, investment has many risks to local communities and their environment. In the same manner, people of Sebeta town are encountered a number of investment related problems alongside its benefits.

\section{Statement of the Problem}

Studies have been conducted in a range of countries to document and analyses investment projects and their impacts on local communities. Governments and corporations have been acquiring large tracts of land in developing countries (World Bank, 2010; Geary, 2012). A public debate among international organizations, researchers and environmentalists is developing regarding opportunities and threats of investment in Africa by investors.

Investment brings good opportunity to developing countries and for investors as well. But, it also has its own drawbacks if not handled well. The most frequently noted negative impact of investment on local communities was reduced access to land (Vhugen, 2012). Particularly, investment has contributed to employment creation, foreign exchange and transfer of technology, skills and knowledge in to the economy (Isabelle, 2015). On the other hand, it has risks such as releasing wastes to the environment of local community, displacing households and dismantling their normal livelihood (Songwe and Deininger, 2009).

Abbink (2011) states that, Ethiopia is in the forefront of handing out land. More than 180,000 hectares of land along the Omo River in southwest Ethiopia has been given for investment where various agro-pastoral peoples (Bodi, Me'en, Mursi, Hamar, Karo, Nyangatom,), who survived there for centuries and use the area intensively. Consequently, protests broke out by local people and were suppressed by government militia forces.

Concerning the area under study, a lot of changes have taken place since 2004, a period when establishment investment projects in the town and thousands hectares of land given to investor(s). As the main development corridor of Oromia, the trend of investment in Sebeta town is enormous. However, the impact of this situation has not been studied wisely. For example, Dejene (2016) studied impact of urban sprawl on farm lands, the case of Sebeta town. Fayera (2005) conducted research on impacts of Addis Ababa expansion on farming community on peripheral area. Teshome (2014) wrote his PhD dissertation on The Transforming Power of Urbanization: Changes and Uncertainties among the Farming Community in Laga Xafo-Laga Dadhi Town. From the themes of these studies, we can see that none of them has dealt with the overall challenges and opportunities of investment projects on the livelihood and environment of the people rather than the expansion and power of urbanization on the farming community. In addition, Ermias (2009) studied prospects and challenges of real estate development on livelihood of rural communities: the case of Lega Tefo Lega Dadi. Kuma (2012) studied performance, challenges and prospects of private investment in Sebeta town. These studies are failed to give emphasis on all investment projects and their opportunities rather than focused on real state and private investment alone respectively.

The area is also believed to have high potential for the growth of investment due proximity to capital city, relatively availability of basic infrastructure and favorable landscape. However, there are complaints against investors as majority of them did not develop land they have been allotted for investment purposes. Studies suggest that some projects are carried out without consultation with local communities and without their knowledge (Getnet, 2012). Moreover, there are grievances on certain companies due to releasing wastes to rivers and open field land areas of local community without proper treatment. Thus, on certain companies, local people complain about bad smell, health problem. Untreated wastes also damages animal health and generally affects the living and non-living things in the environment. In light of this, the study was initiated and aimed to examine the challenges and opportunities of investment to the people of Sebeta town.

\section{Objectives of the Study \\ General Objective}

The general objective of this study was to examine challenges and opportunities of investments to the people of Sebeta town, Oromia regional State.

\section{Specific Objectives}

$>$ To identify the opportunities that investment brought to people of Sebeta town. 
$>$ To explore the major challenges that occurred due to the investment in Sebeta town.

$>$ To examine how people of the town perceive the investment.

$>$ To examine the coping strategies of the local people to overcome the challenge of investment expansion in the study area.

\section{Research Questions}

The research questions proposed for this research were originated from the practical problems that initiated this study. The following research questions developed for this research are based on the statement of the problem as follows;
$\checkmark$ What are opportunities investment bought to people of Sebeta town?
$\checkmark \quad$ What are the major changes and challenges that occurred due to the investments in Sebeta town?
$\checkmark$ How do inhabitants of Sebeta perceive investment?
$\checkmark$ What are the coping strategies of the local people to overcome the challenge of investment expansion?

\section{Scope of the Study}

This study was delimited geographically, thematically and methodologically. Geographically, the study was conducted on Sebeta town where large numbers of investment activities are taking place. Thematically, the study focused on challenges and opportunities of investment to people of Sebeta town. This study covers investors/managerial staffs, workers of selected companies, people who lost their land due to investment purpose and affected people by investment projects and youths of the town. Methodologically, this study used a qualitative approach and the methods used in the collection of data were interview, focus group discussion, observation and case study.

\section{Theoretical Framework}

Theory/model is/are mainly used to see how things work and to test our data whether it is valid/invalid or applicable/not. Accordingly, during the course of my fieldwork, I found out that the on-going investment activities in Sebeta town can be reflected through two extremes. These are 'development' thesis and 'culturalist' anti-thesis. The 'development' thesis contends that investment will foster development and lead to technology transfer while its 'culturalist' anti-thesis emphasizes the fact that investment alienates small-holder agriculturalists and indigenous communities from their traditional rights to land, thus endangering domestic production and food security (Lay \& Nolte, 2011). Therefore, challenges and opportunities of investment to people of Sebeta town can be addressed via these two theories.

Moreover, 'basic need approach' is also important for the problem at hand. In the mid-1970s, the 'basic need approach' was popularized by the International Labor Organization (ILO) and subsequently by the World Bank (WB) (Seers, 1970; Streeten et al., 1981). This approach argued that development projects should give priority to increasing the welfare of the poor directly through projects targeted at improving food security, education, housing, health and so on. To do so, the three pillars of sustainability (economic, social, and environment) need to be incorporating one another and Ethiopian government need to compel to an 'integrated approach' that fully considers the interest of people of Sebeta town. Generally, the sustainability paradigm rejects the imbalance among its three pillars (environmental, social and economy. Instead, sustainability is a paradigm for thinking about a future in which environmental, societal and economic considerations are balanced in pursuit of development and an improved quality of life (Mckeown, 2006). In this way, the Ethiopian government's strategy, Agricultural Development Led Industrialization (ADLI), can be successful (achieve its goals) and Ethiopian people can be alleviated from food insecurity and poverty. Therefore, Ethiopian government's strategies are on the verge of falling unless integrated approach is not implemented (Azeb, 2017).

\section{Research Site}

Sebeta town is one of the urban centers in Oromia special zone surrounding Finfinne (Addis Ababa) situated at about $24 \mathrm{~km}$ on the south western direction of the capital city of Ethiopia along Finfinne (Addis Ababa)-Jimma road. Oromia special zone surrounding Finfinne (Addis Ababa) was established in 2005 by combining some parts of the north shewa, east shewa, south west shewa, and west shewa zones. At present, there are eight towns including the present research site that fall under the administration of this special zone. Therefore, in all directions the administrative center of the zone is Finfinne (Addis Ababa). Sebeta is dominated by different chains of mountains including Wochocha, Mogle, and Furi Mountains.

Regard to relative location, it shares common boundaries with Addis Ababa in the north, north east and east, Burayu town in the north, and rural villages of Sebeta Hawas district to the north and west (Atkure and Ahmed, 2013). Astronomically, Sebeta town is located within an approximate geographical coordinates of $8^{0} 53^{\prime} 38.50^{\prime \prime}$ $\mathrm{N}-8^{0} 59^{\prime} 58.17^{\prime \prime} \mathrm{N}$ latitude and $38^{\circ} 35^{\prime} 11.91^{\prime \prime}$ E- $38^{0} 39^{\prime} 33.75^{\prime \prime}$ E longitude on the globe and its average elevation is 2365 meters above sea level (OUPI, 2007). Currently, the town has eight Kebeles which include 
Sebeta (01), Alemgena (02), Walete (03), Furi (04), Dima (05), Daleti (06), Sebeta (07), Kerabu (08) and 09 Kebele (Furi Gara Bollo).

\section{History of the Town}

According to data obtained from the municipality of Sebeta town, Sebeta and Alemgena had emerged before the Italian invasion in 1935 and it has got municipal status in 1954. Formerly Sebeta (the current 01 kebele and 07 kebele), Alemgena (the seat of the current 02 kebele) and Woletie (the current 03 kebele and part of 04 kebele) had been developed separately following the road from Addis Ababa -Jimma. The informant also told me that regardless of its location at the border of Addis Ababa city administration and along the road from Finfinne (Addis Ababa)-Jimma, Woletie has shown urban character in 1990s and has become part of Sebeta. A record from Sebeta municipality shows that the town was formally given the status in the year 2005, although the area (Sebeta town) was under the administration of 'Aanaa Sabbataa Awaas' (Sebeta Awas district) of south west shewa zone.

One of my informants among local elders told me about the nomenclature of the town as follows;

The town gained its name 'Sebeta' from different assumption, which of course results no basically changes of its meaning. The name 'Sebeta' (Afan Oromo in origin) literarily means a scarves like textile mostly women used for wrist betting, with collared at both ends. One of the ancient ruling kings of Jimma, namely Abba Jifar, on his way travelled from Jimma to Addis Ababa, named several towns on the way and at last arrived at Sebeta Town. Since his followers on the travelling exhaustively tired of the long journey, to encourage his followers and for demonstration, they approached to Addis Ababa city, Abba Jifar, the accompanied ruler, instructed verbally "Sabbata keessaan jabbeeffadhaa" meaning make strong your back bone by traditional belt known as 'Sabbataa' to encourage his followers when they were close to Addis Ababa. Then, it has assumed the local people, since then, began to call the area as Sebeta, and thus remained the favorite common name of the town.

(Source: Interview, April, 10, 2019, Alemgena).

According to the data obtained from Sebeta town municipality, the current total population is 336,975 , of 139,131 men and 197,844 women. The total area of the structure plan of Sebeta town prepared by OUPI in 2008 was 9827 hectares. The area of the town increased to 17,503 hectares in the structure plan revision of 2018 by OUPI. The area increased by 7676 hectares in 2018 . The town has shown tremendous physical growth of $78.1 \%$ towards southwest, east and northeast directions though almost all activities are concentrated along the highway to Waliso and highway to Butajira (OUPI, 2018).

\section{Research Methodology and Data Collection Methods}

The research methodology in this study is more of a qualitative type. Additionally, the quantitative approach is used to supplement the qualitative data by providing quantifiable evidences that reveal the impact of investment on the town as a result of the investment projects expansion in the study area. In order to collect the necessary qualitative and quantitative data, a combination of instruments is used so as to make every data complement each other.

Qualitative approach has been used to collect the perception and attitudes of people in the study area regarding the socio-economic changes and challenges and opportunities of investment activities. In addition, this approach has been used to explore the opinion of the informants from the people regarding the level of participation in planning and implementation of investment activities in their locality.

To do so, interview (semi-structured interview), focus group discussion (FGD), observation and case study were employed to generate data from different sources. In addition to the primary data, secondary data was used.

Purposive and Snow ball sampling were used to select the participants for the qualitative data where informants were selected based on their experiences. They were also selected based on age and sex characteristics to capture the view of various community members. Participants working in different government institutions were purposively selected based on the responsibilities they have in their respective institutions. In such away, 141 individuals were directly participated in this study. On the process of the interviews, there were situation in which some informants informed me to other informants who had better understand of the situation.

\section{Interview}

Interview, in most qualitative research, is taken as a process of communication or interaction in which the subject or interviewee gives the required information orally in a face-to face situation (Teshome, 2014). In this study, I used semi- structured interview methods. Thus, issues concerning the subject under study were collected through developing interview guideline that contains a series of open ended questions. In such way, interview was conducted with government officials (Investment Office, Labor and Social Affairs Office, Land Administration, Environmental Protection Office, Urban Job Creation and Food Security Agency and Culture and Tourism) in various times to understand their views and concerns about investment and its impacts on the 
individuals' life.

Moreover, displaced people were selected for interviews to express their views regarding the investment process in their locality and the resulting outcomes. Accordingly, 31 displaced people were interviewed. Workers from different investment sites were selected by considering their sex, marital status and age and interviewed on the impact of investment. Hence, 36 workers from different investment sites were interviewed. Investors/managerial staffs of some selected investment projects based on their magnitude of impacts to people of the town were also participants of the interviews conducted at various time. Accordingly, 12 companies' managers were interviewed.

In general, informants were selected by considering their diverse experience in terms of their experience, age, work, position and gender.

\section{Focus Group Discussion}

A focus group discussion was conducted to facilitate the discussion among a small group of the entire. In this study, focus group discussion was used to produce information on topics that require group viewpoints and sometimes consensus or disagreements. It helped to capture and understand challenges of investment on local people, the impact of losing land to investment on households, the changes observed on environment after the advent of the investments and opportunities of investments to local people. Based on the above rationale, I used this method by organizing four focus group discussions including of 8-10 participants were conducted.

The first FGD was held among displaced people. It constituted nine displaced people. The second two FGD were conducted with group of men and women workers of some selected investment projects which constituted eight and ten members respectively. The fourth was conducted with the youth selected from the town depending on their awareness of the situation I was interested in. Accordingly, nine youths were participated in focus group discussion.

In general, a total of four focus group discussions were conducted to gather the data for this study. I undertook the discussions by preparing checklist for focus group discussion and at suitable time and place selected depend on the agreement of the participants. Generally, the purpose of focus group discussion was to generate and cross check data gather from individual informants and to gain general information about the challenges and opportunities of investment in the areas.

\section{Observation}

Observation provides an opportunity to get beyond people's opinions and self-interpretations of their attitudes and behaviors towards an evaluation of their actions in practice (Gray 2004:238). In carrying out this study successfully, I negotiated and made relationship with the people, government officials, investors and workers for observation activities after I explained my objectives and presented the reference letter from the University to them. In the course of fieldwork, I observed, manufacturing, agro-industries, flower farms, real states and others which are under construction projects and occupied land by investors and fenced for a long period of time. Most of the observations were chance-based to cross check if the data I collected through other techniques match with what is real on the ground. In such away, I took photograph to support the personal observation. This helped me to see what are on the ground regarding investment activities in Sebeta town. Hence, I was in research site in order to carefully observe what is going on from the beginning to the end of the field work. In general, observation was so important for me to capture the practical occurrence on the ground to strengthen the data obtained through interview, focus group discussion and case study.

\section{Case Study}

I documented two of actual cases that happened on local people by investments in the study area. These include affected households/individuals about the effects of losing land to companies on their incomes and livelihood in general. So, life histories were analyzed and interpreted by examining the subjective experience of individuals. Therefore, life histories of individuals were drawn in the due process of the interview in the field work and incorporated into results and discussions section.

\section{Secondary Data}

Primary data need to be supported by previous research and other documents in order to make this research richer in data and strengthen the argument for its accomplishment. Hence, I used secondary data such as available books, proceedings, research reports, journals articles, newspapers, electronic materials, Proclamations, Constitution of the Country (Ethiopia), Investment Contractual Agreement, Ethiopian Investment Policy, Ethiopian Environmental policy, and other relevant literatures.

\section{Data Analysis}

Data analysis is one of the most important stages of any research. It is a step-by-step examination of issues and 
their connections. In anthropological studies, analysis is an instrument to extract meanings from the information obtained during the field work (Teshome, 2014). Any researcher has the responsibility of analyzing data to meet his/her objectives as well as to make the findings ready for scholarly consumption. The analysis was guided by the research questions and objectives. Therefore, after data collection completed for this study, I copied information from tape record and gave meanings. In general, the qualitative data was presented in a descriptive form throughout the writing in such a way that it helped for further interpretation and the making of meanings.

\section{Results and Discussions}

After relevant information was collected, data presentation and analysis are the necessary step. Hence, this chapter includes results and discussions of data that were collected through primary and secondary sources. Interview, focus group discussions (FGD), case study and observation were techniques employed to collect primary data on challenges and opportunities of investment on people of Sebeta town. Secondary data were also utilized in the presentation and analysis part of this paper.

\section{Opportunities of Investment}

Ethiopian government uses investment as one of the most important and effective strategies for economic growth, food security, and poverty reduction in the country (Azeb, 2017). Major sectors of investment created thousands of temporary and permanent of job opportunities. As the town is very close to the national market and major international and national outlets, investments especially manufacturing industry dominates comparing to the other economic sector. Hence, the main opportunity of investment in the study area is expanding of livelihood options for local people through job creation. Getting a job can increase local standards of living and help employees to manage their ways of lives in a good condition.

For some, investment came up with several opportunities. As obtained data from interview with TM, he stated his success history as follows;

Case 1: Mr. TM was one my informant among displaced people. Mr. TM was totally evicted from his farm land 4 years ago. Now, he is living in Furi Gara Bollo (09) kebele of the town. Mr. TM, after obtaining a compensation payment, he built 11 rental rooms in his residential compound. As he said, "each of the rooms now is rented with 600 hundred ETB per month." It means he earns 6,600 ETB; it is equivalent to 231.57 USD per month. As he describes in terms of cash, he earns much more than in the past. As to him, now he is able to buy 2 laptops for his 2 children who learn in Adigrat and Adama Universities. He is able to cover his home and his children's monthly expenses. In fact, Mr. TM noted before he spent the money elsewhere, his sons advised him to build a rental houses. As he said "my first plan was to buy a cart for local transportation purpose but lately my sons advised me and turned me to this business.

\section{Job Creation}

Thousands of people get jobs in investments activities from daily laborer to a highly demanding professional job. A number of people's live have been changed as a result. According to data gathered from investment office of the town, there are around 782 investment projects. These investment projects opened job opportunities for more than 60,124 people, out of these, 50,123 created by the manufacturing sector. Town with high economic growth attracts potential investments and creates employment opportunities. From the economic activities of the town, manufacturing sector is the one in which many job seekers get job opportunities. However, still many rural migrants and newly graduated students are in search of jobs in the town. Not only job creation, investment also has own crucial role in technology transfer.

For instance, Ayka Addis Textile and Investment created job opportunities for about 10,000 Ethiopians. It also uses raw materials such as cotton from domestic market creating linkage for local economy. Furthermore it benefited the country by generating foreign currency. Partial view of the factory is seen in the following photo that was taken by the researcher during field observation. 


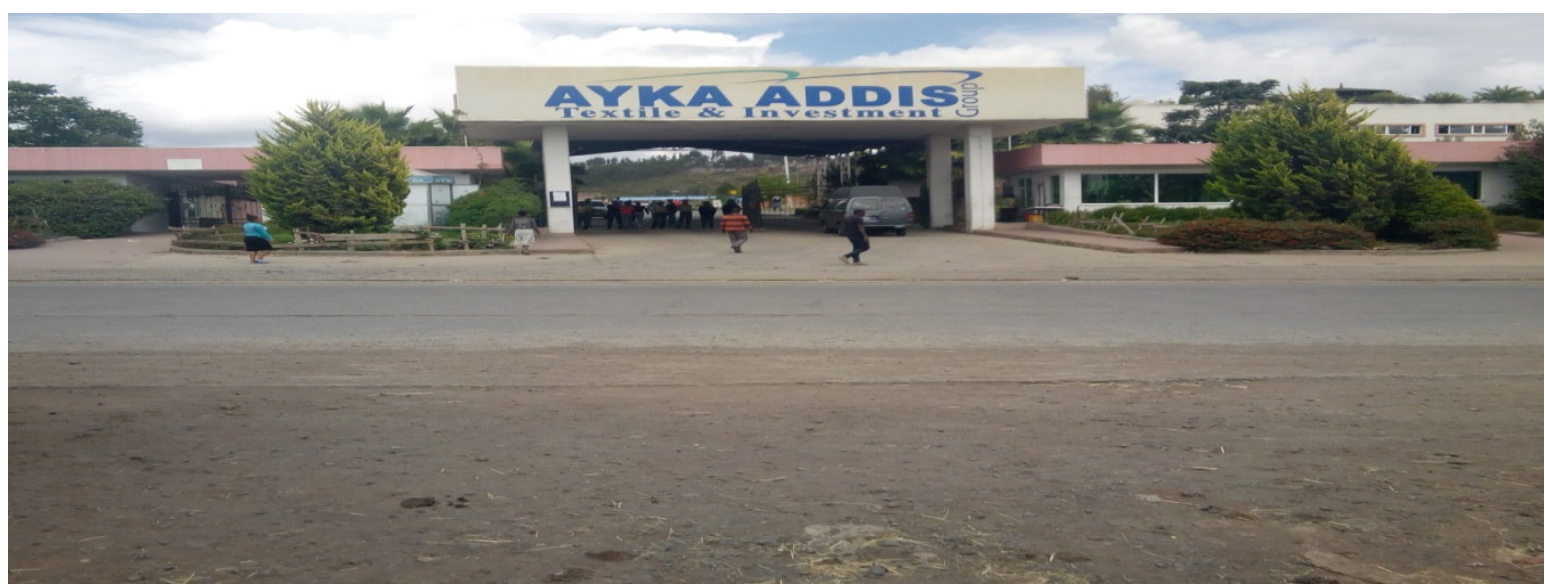

Figure 4: Partial photo of Ayka Addis textile and Investment (May, 07, 2019).

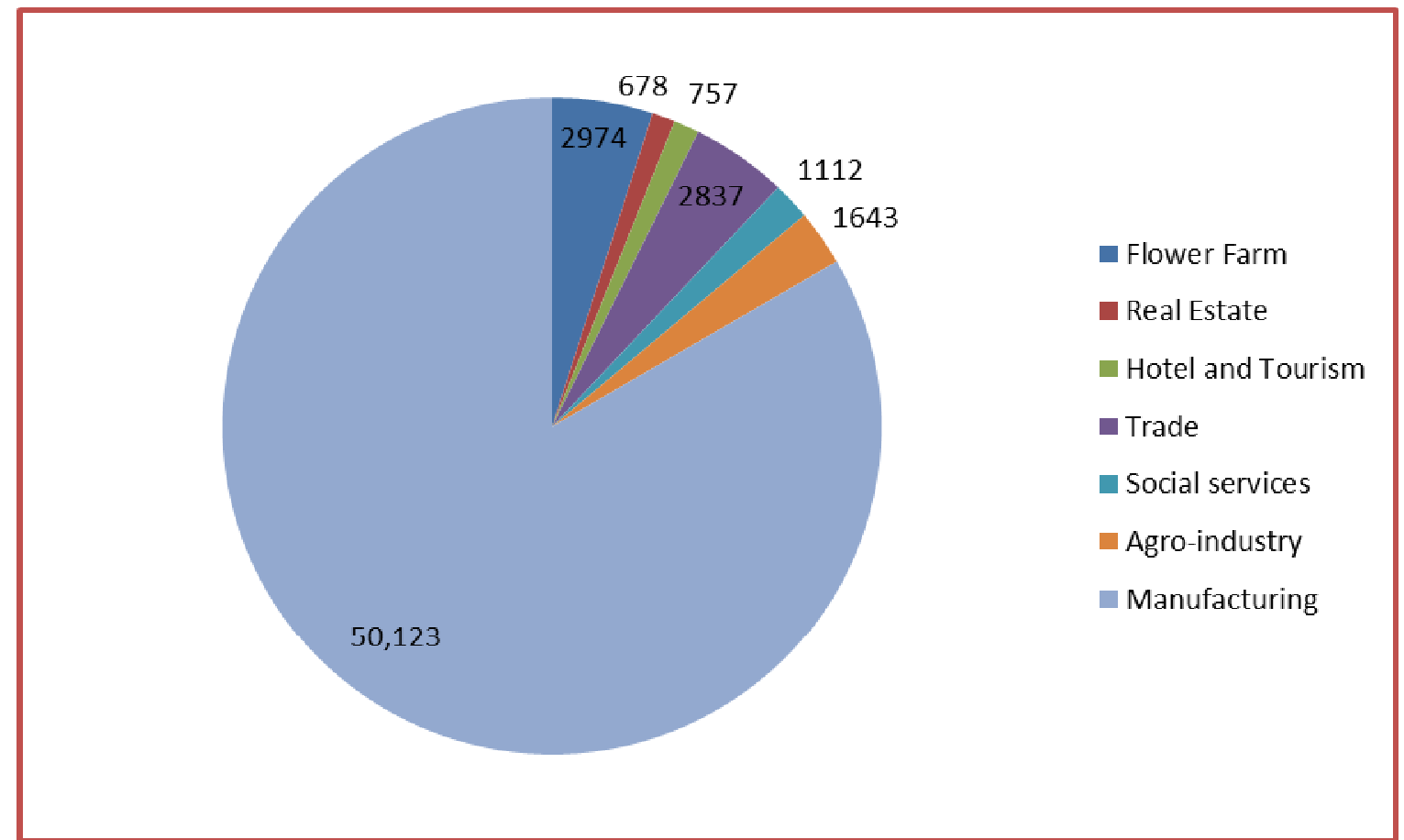

Figure 5: Employment opportunity created by the investments in the town (Source: Sebeta town administration investment office, May, 2019)

Manufacturing sector is the leading in number of firms, amount of capital, occupied land area in hectares and employment opportunity. Flower firms and commercial firms are the two investment sectors creating large employment opportunity next to the manufacturing sector, $(2,974)$ and $(2,837)$ respectively.

\section{Technology Transfer and Community Service}

One of the objectives of attracting investment is to foster the transfer of technical knowledge, skills required for the progress of the country. Technology transfer, diffusion and skills training should be taken as one among the key competence areas of industrial investment to be competitive in their products.

Accordingly, there are investment projects perceived positively by most community members interviewed because of making the people beneficiaries through providing training for locals on bee farming (Soziit honey and wax agro-industry), pure water (Tal flower farm), sponsoring local events and building recreation center (Meta Abo Brewery), digging and building public toilets (Huda Construction), helping the vulnerable and orphan children (Raphi Soap detergent) are few.

The company like (e.g. Best Plastic Factory) is perceived positively by most community members interviewed because of making the local people beneficiaries through providing various services such as pure water, and uses significant proportion of raw materials from local sources. 


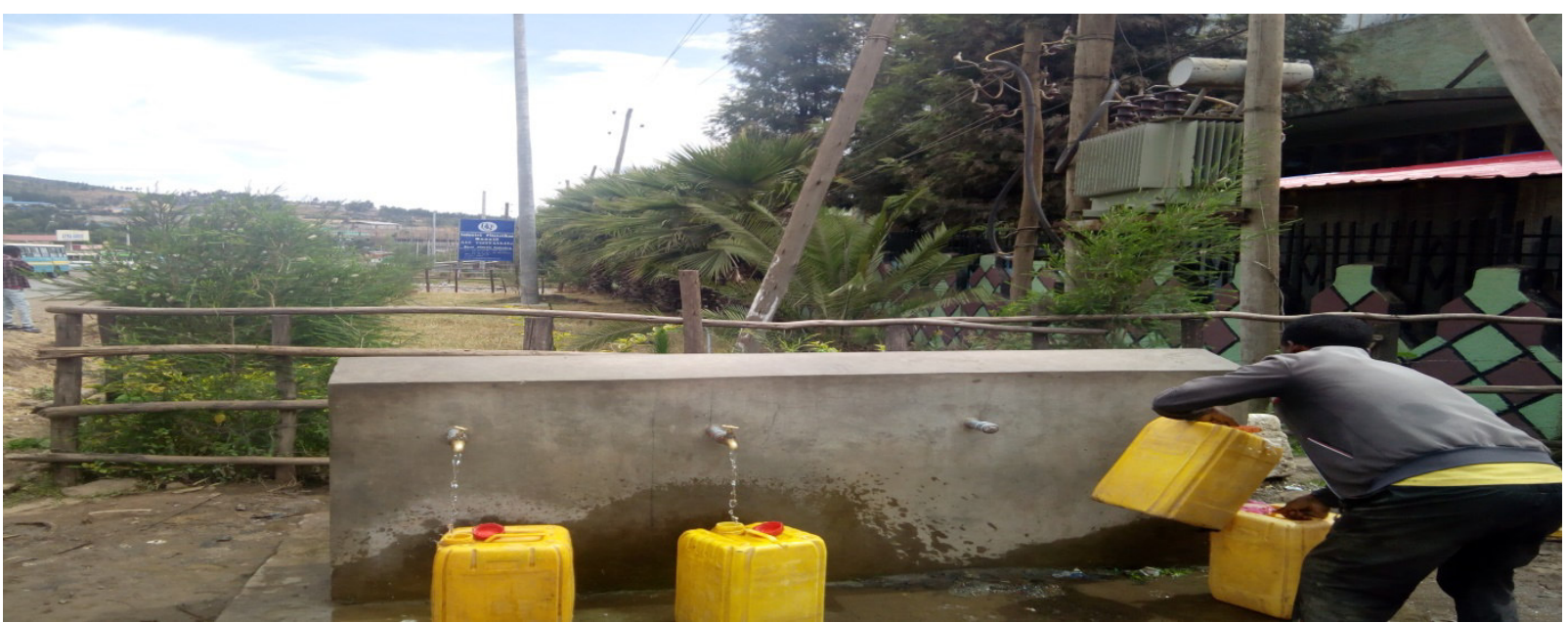

Figure 6: Water provided by Best Plastic Factory for public (Source: Picture taken by the researcher during field observation on May, 2019).

\section{Major Challenges of the Investment}

Initially farming was the mainstay of the inhabitants in the study area. Through time, socioeconomic features started changing mainly from farming to daily labor, petty trade and micro and small enterprise. Now, high investment in the area resulted in high job opportunities most of the residents are working in industries about 60,124 individuals, mainly as a daily laborers or semi-skilled professional. Data obtained from interview show that there are two major socioeconomic changes;

1. Location shift of farming practice from sub-urban areas to more peripheries.

2. Changes of livelihood from farming to petty trade/own business and daily labor.

With regard to economic changes, mainly agricultural production and productivity changed in the study area. In addition to that high migration due to economic and investment activity increased over the past one decade attracted people from different parts of the country. Areas that were previously cultivated changed to industrial areas. Farmers in the periphery changed their land to other forms, like sold for others, houses constructed, take over by investment activities. In the past one decade, more specifically in the past five/six years, the trend of investment in the town is enormous. A number of manufacturing plants and associated service and related factories are established. As a result, some challenges have been occurred to people of the town. These challenges are discussed as follows;

\section{Investment Related Challenges}

The establishment of investment projects is increasing in Sebeta town. However, there are basic hindering challenges. Firstly, some of the investment projects (for example, HAFDE, Balazaf Alcohol Factory) are nominal and do not invest trust-worthily. Some others start building and stop after a certain period; others fence and rent the land rather than the intended purpose which the case is getting worse as the concerned authority did not took immediate measure for such occurrences.

As Vhugen (2012) stated, investment has risks such as loss of land, conflict and social unrest, unsustainable resources use and environmental degradation. At the beginning, I have been to Dima (05) where I observed many socio-economic problems related with displacement for investment purpose such life after displacement and their access to social services. The problems of households displaced from their land overlooked in the name of development.

\section{Land Expropriation}

Government of Ethiopia is providing land for investment with a variety of incentives such as repatriation of profits, hiring expats, custom duty exemption, income tax exemption and etc. It believes that investment is a crucial way to fight poverty among other approaches, is to make use of available natural resources. However, this exercise is not positively viewed in all corners and which benefits investors at the expense of the people. Hence, it ignores the culture and identity of local people and is being implemented through displacing of local from their land, which sometimes leads to violence, death and destruction of property (e.g. burned factories in Sebeta like Sygen Dima). In Sebeta town, as in other parts of the country, the attention focuses on allegations that people are being displaced from their land in order to make space for investment. Though it is known to be an autonomous town, these days, it is almost difficult to find a spatial boundary of this town with neighbor towns and rural kebeles. This has happened as a result of the establishments huge investment projects like flower farms 
and manufacturing industries.

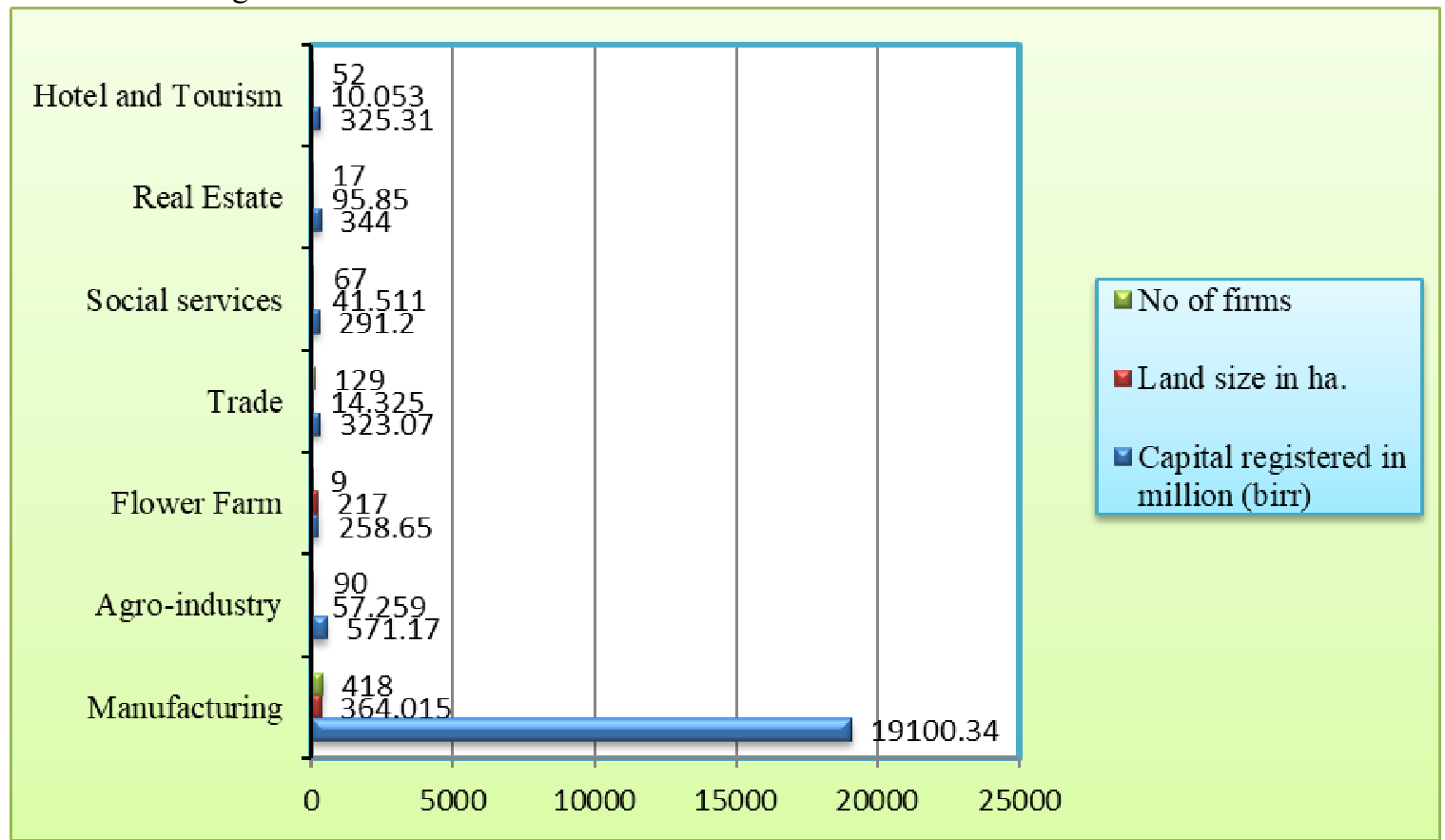

Figure 7: Total Investments by number of firms, capital registered and land size (Source: Sebeta town administration investment office, May, 2019).

As illustrated in figure 1, above, manufacturing takes the major share in number of firms; capital registered and land area in hectares. Accordingly, the manufacturings are 418 in number $(53.45 \%)$ by registering about 19.1Billion ETB (88.84\%) and occupying the land area of 364.015 hectares $(45.50 \%)$. Trades take the second part in number of firms $(129,16.49 \%)$ and 5th and 6th in capital and land area coverage. Next to the manufacturing, the largest hectares of land occupied by flower firms and real estate, $(217,27.12 \%)$ and (95.86, $11.98 \%$ ), respectively. On the other hand, like as the largest amount of capital and hectares of land occupied by manufacturing industries, the largest number of employment opportunity also created by this sector $(50,123$; $83.37 \%)$

\section{Environmental Pollution}

Some industries generating liquid wastes, solid wastes (especially the under composed materials, plastics), etc. Polluting the environment is a serious problem in Sebeta town. During the field visit, I observed that animals drink Sebeta River which carries wastes of factories alongside to the river. One informant during focus group discussion said that "I lost one milking cow in 2018. It drank this river and passed away". Other participant of the interview also share this problem and added that, had it not been the situation improving we could have lost many animals.

Most of the high water consuming industries in the Awash basin area draw water for production purposes from water supply sources and discharge their by-product wastes in to streams and rivers without any kind of treatment. Besides this, there is no restriction on industrial plants discharging their waste water into the rivers and water courses. The below photo was taken during field observation. It was the waste releasing from Ayka Addis to the river. 


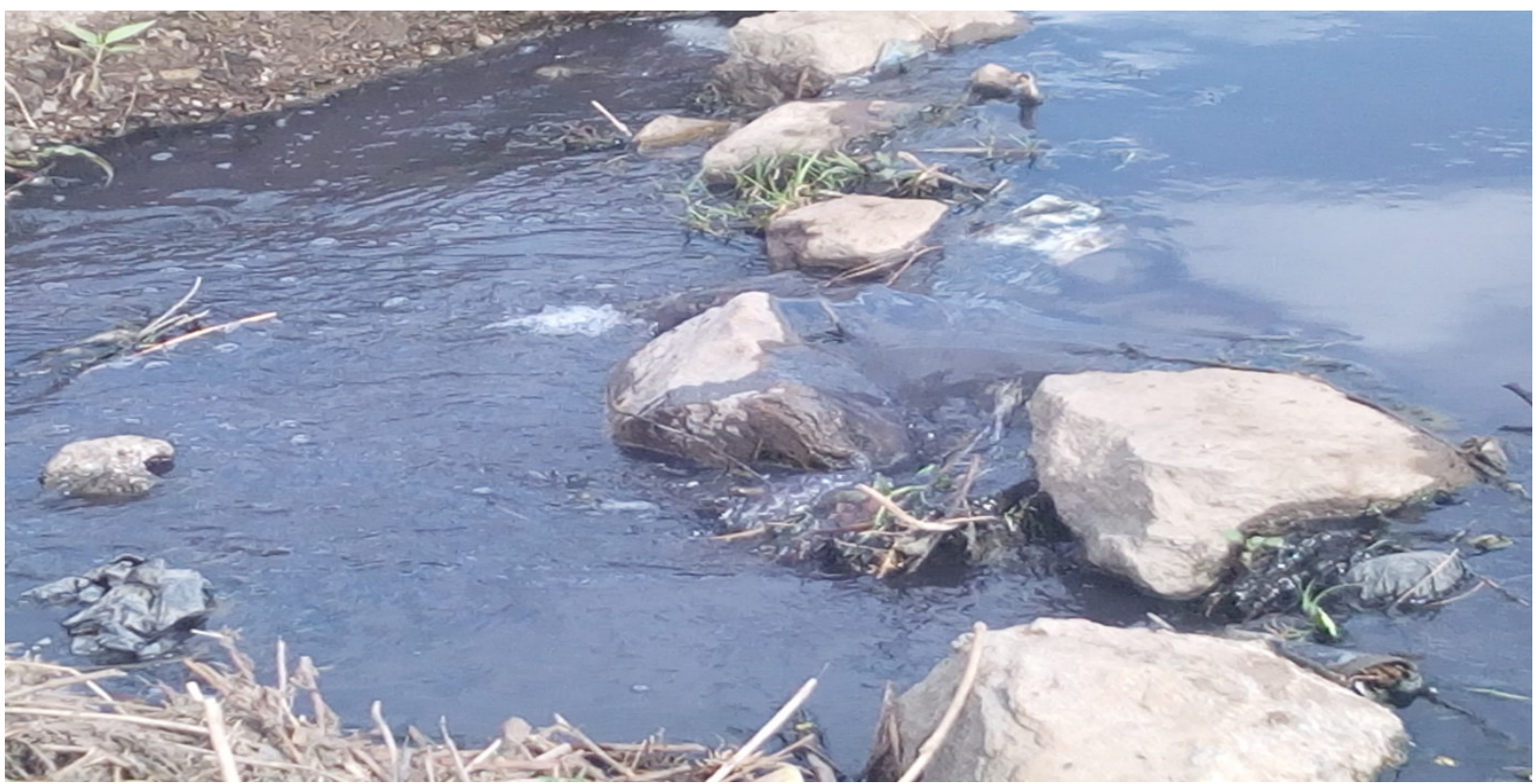

Figure 8: Liquid wastes discharging to the river (Source: Photo taken during field observation on May, 2019).

One of the participant of the focus group discussion said that, "we sometimes use the polluted water for irrigation, we have no another option but it will affect our health, i.e. resulted in itching of our leg and feeling of discomfort on our health. We will farm it when the rain is coming at least it decreases its pollution effect". According to data obtained from interview with town's Environmental Protection and Greeneries office, some investment projects became environmental challenges. For instance; Haffede Tannery Industry has been built on the side of the river and Finfinne (Addis Ababa) to Jimma main road. It discharges liquid wastes to the river without proper treatment. Due to this, decision to close taken over it in 2017. However, sister company (garment) inside it still on working.

Again, according to the data obtained through interview from the office, Haffede Leather Industry is one of the major export earnings in the manufacturing industry in Ethiopia. However, there is a challenge in tapping its economic benefits with minimizing its pollution effects to the environment. It becomes delicate to maintain practically both keeping the environment sustainable and growth of the industry. This shows that implementing environmental policy of the country in harmony with the required growth of leather industry becomes a difficult task for the government. Another factory that damages the environment in the town is Balazaf Alcohol factory. The environmental protection and greeneries office's expert stated it as follows;

Balazaf Alcohol factory had released 'Terefe Mirt' (left output) to the river against the environmental protection rules and regulations. Farmers and their production both livestock and cereals were affected by this 'wastes released from the industry'. The factory built treatment plant costs around 80 million ETB, although it hasn't used because of power shortage. Due to this, the company ordered not to use the molasses and that releasing to the environment so far

(Source: Interview, April 10, 2019, Sebeta).

The above response show that the waste released from the industry has harmful effect on the environment. Untreated wastes also damages animal health and generally affects the living and non-living things in the environment. Hence, it has adverse effect on the environment and human if it is not properly managed.

In the same manner, the office of Environmental Protection and Greeneries stated the impact of Meta Brewery that, although the factory improves many things such as environmental conservation, reducing amount of wastes, but the liquid waste is not eliminated at all. The water, polluted with this liquid wastes released from the factory, is not good or suitable for drinking and for other usage. These imply that the factory discharges their wastes into nearby water bodies and open land with little form of treatment. This implies that the implementation of the policies especially to penalize industries who does not follow the rules and discharge waste without treatment to river is slight.

Again, as the data obtained from interview with Environmental Protection and Greeneries office shows that Gedeong Garment, capacity of the treatment plant built by the factory and amount of water it release not match. The town's administration environmental protection and greenery office advise them to reduce the released amount of polluted water discharged to Atabala River. A year ago, the factory was closed since it did not bring any changes from this regards. However, now a day the factory on works showing some improvements in reducing pollution of water. But, it does not able to eliminate all in all released polluted water to Atabala River. Hence, the release of waste has not been regulated until this data collected. 
Another factory that was contributing to environmental pollution is Blue Nile Factory. As the expert of office of Environmental Protection and Greeneries told me that Blue Nile Leather Factory...First of all it was not built at the right place. The factory was built at River side and existing in the residential area and school side. The factory built tertiary treatment plant; however, it was not successful. Due to this, the factory is still closed. The question here is closing can be the end solution? Because, there is no measurement taken over such factories than closing. Now, there is no what they were contributing to the town's or country's development.

As I observed during field work, the Flower farms also releasing the polluted water to the farmers' farm. I asked the Environmental Protection and Greeneries which is a responsible for this issue. As the interview with Environmental Protection expert revealed that the flower farms owners claim that they belong to the federal government. In a sense they, can't obey to the town's environmental protection and greeneries. Furthermore, the community has complained over the flower farms as the chemical usage of the farms affecting bee farming. This implies that such chemicals threaten human health and ecosystem function as a whole.

According to the data obtained from interview with one informant from member of the community stated his ideas as follows;

Minaye packaging is a factory that contributing to environmental pollution in Sebeta town. It was closed so far for releasing liquid waste to the environment, but now it is on work. We are living here around the factory. Finally we collected petition to the town administration environment protection and greeneries office asking to close the factory.

(Source: Interview, April 10, 2019, Sebeta).

This shows that Factories are contributing to the loss of the well-being of the society and are one of the causes for the society's health problems. In principle, development activities of the country are meant to make the lives of citizens better off. But if the benefits people get out of development activities such as the development of industries is overwhelmed by the problem they face, it is considered as undesirable to society.

As the data obtained from interview with the expert of the office of environment protection and greenery, another challenge one for the environment is Plastic producing factories. They are over seventy in number in the town. They are distributed in the town unevenly. Most of the plastic factories are not practices recycling the outdated products. Some of the factories undertake the recycling, but factories released bad odder while recycling. In the same manner, Capital Cement sometimes releases urine from their own toilet to the surrounding drainage canal and to the open areas. Furthermore, based on the research result of the town administration environment protection and greenery office, the factory shutdown last due to the dusts released from within. But, this day the factory is re-instigate as it imports machine from abroad and able to retain the dusts within.

Generally, as the above examples show that some investment projects in the town seem like irresponsible investment for environment. Also, industries established along the river side and main road and industries mixed with the residential houses and releasing wastes to river streams should be relocated/must use treatment plant not to releases even bad odder. As result of this, many rivers and streams are heavily polluted as they flow through the town. Hence, this study is very limited and not addresses the whole pollution problem in the town.

According to data obtained from interview with one of town resident revealed that the negative effects of investments are discharge chemical waste, labor exploitation and misuse land allocated for investment purpose. This issue is raised also in focus group discussion with displaced people. As per the focus group discussion results, some plants (such as grass) dried, water was contaminated (rivers in the town) and some trees were severely affected and stunted by the chemical waste. However, except few number of investment projects, the Sebeta town administration did not respond to community's complaints about the investment's irresponsibility on abuse the environment and exacerbating the growing tension between investors and local people.

As discussed above, certain industries off their normal operation due to measures taken by the town's environmental protection office due to polluting the environment and river streams. After measures taken over the selected manufacturing industries, the industries cut off all the work forces worked in the industries for years, and stop production. The closed industries neither relocated nor operating. This situation brings significant pressure on the country's economy (trade balance, currency inflow), employment opportunity and psychological and social impact in general and on the town in particular.

In general, lack of environmental impact assessment before land is leased to investors has been one of the most burning issues which surfaced in this study. Failure to assess and implement findings of the environmental impacts assessment of investment project is likely to lead to tension among government, investors and local people.

\section{Resistance and Instability}

As land expropriation and forced displacement for investment purpose continue throughout the Oromia region in general and Sebeta town in particular, local people resisted to land dispossession has emerged. As one informant from displaced people during interview elucidated that from the very beginning, the oppression of the state has led to opposition of citizens through a variety of demonstrations. Many peaceful protests have been brutally 
repressed by police, protest leaders have been arrested and detained and mostly their complaints have been ignored in the last four years ago.

Informant told me that the main cause of local people movements is against displacement with inadequate compensation. Many local people have resisted to defending their land and fighting against the government. However, then problems remain unsolved. Informants expressed feeling of hopelessness. "Homtuи kan nuи dhaga'u hin jiru, yoo jarri ammaa kun nuuf dhaga'e malee" (nobody gave attention for us, we hope the current government give hear for our grievance). Therefore, the best they can do is to facilitate reasoned discourse among the interest groups.

\section{Displacement and Loss of livelihood}

In the study area, the establishment of investment projects dispossessed local people from their lands which are their main livelihood bases. However, a few of them are remaining with small size lands that are not sufficient to support their families living condition. This is because they were obligated to give up their land holding thereby loss diversified livelihood activities.

Mass numbers of people have been affected by displacement. More than 1315 hectares of land have been transferred from people to investors for investment purpose (including operated, under construction and not invested and simply fenced land).

According to one informant from displaced people during focus group discussion explained that key actors who involve in displaced us is government in collaboration both domestic and foreign investors. They have taken out our land through violent force and unlawful process. Displaced people mostly have not received proper compensation. This informant also stated what she faced as follows;

Initially, I was a farmer before my land taken out by investors. I have eight children. I have no other experience than farming. My land is already taken by investor last eight years ago (2011). The government gave me very few birr, 15,000.00 ETB (526) for three hectare. "Osoon lafa sana sitti agarsiisee dhugaadha hin jettu, isa waaqni guddaan haa dubbatu" (you don't believe if I show you that land, I gave my truth to God). "Qe'een koo humnaan narraa fudhatame. Akkan dinnicha dhaabee daraaree jirutti balleessan" (They took my compound forcefully. They cleared my immatured potato in my compound with bull dozer). However, until now they did not invest it. They unable to create job opportunity for us. I unable teach all of my children. Now, three of them dropout of school.

(Source: Focus Group Discussion, April, 20, 2019, Dima).

This response shows that the implementation of rule of law is very slight. Even if the above mentioned farmer has no any information how his land compensation is estimated, on the purpose of attracting investment into the county is for job creation, technology transfer and currency exchange. However, from the above mentioned, land was taken by the investor, but not serving the local people, government and investor itself. This opinion directly goes with the intention of Proc No.455/2005 which dictates that farmers should be informed and be convinced that their land is going to be expropriated for development projects.

According to data obtained from interview with informant from investment office of Sebeta town, since 2008, the government has awarded thousands of hectares of most fertile land to foreign and domestic investors. Despite the fact that local people were displaced and lost their incomes and livelihoods. Therefore, most of displaced people require assistance to be able to participate in development projects in a meaningful fashion.

One of local people aged 43 and dweller of the urban stated the situation as follows;

I don't know how I tell to you. In the last four years ago, I had two hectares of land in this kebele (04). By the advent of investment, I dispossessed my lands and the government handed out to investors. I did not get sufficient cash compensation. I was not volunteered to displace from my land. The administrative units of the town frightened me as I displace with decided cash compensation and told me that government can take any necessary measurement over you. "As jiraachuf wabii maalii qabna?" (What is the guarantee we have to live here?). I have five children. All are dependent and with me. Then, I rent a house for my family. After six month, the compensation money becomes getting low and I employed in one company as a guard. Still now, I am working as a guard and serving my family". There is no any property what I inherent my children than poverty". He added that "Land is everything. What is the value of money? It is ice, it has gone. If the land is with us, we will free from hunger and miserable life.

(Source: Interview April 10, 2019, Furi (04)).

The above response shows that the displacement is not depend on the willing of the people. Also, there was no any entrepreneurship training for displaced households. These people do not know how to use money. Additionally, the response show that how much they are attached to land for their survival.

Another participant of my focus group discussion with displaced people told me new mechanisms of displacing local farmers. He told me what he experienced during displacement as follows;

I am a father of three children. I engaged in farming. I have two hectare of land. Last five years, the 
local government officials ordered me to displace and take out land for investment purpose with very few cash compensation which cannot reconstruct my livelihood. Hence, I resisted against land dispossession. Then, the government officials take out all land which surrounding my land gave it for investors. The investors started construction on the land which is neighbor of my land. My land left inside. 'karaa natti cufanii, bahaa fi gala na dhorkani' (they locked all direction to me to access to social service. There is no exit). Later, they made me as I displaced. I cannot do anything rather than give.

(Source: Focus Group Discussion, April, 18, 2019, Daleti).

The above response shows that land locked mechanisms is one way that government officials and investors displace farmers from their land.

Case1: Ato NE aged 56, educated up to grade $7^{\text {th }}$ during Derg regime is one of the displaced farmer from 02 kebele. He has 8 family members which dependent and managed under him. Previously, he owned 2 hectares of lands, animals (cattle and sheep) and other developed trees and well organized rural houses, and he is one of the model farmers of the kebele. He has received compensation of 18 birr/kaare.sqm for 2 hectare and 300,000.00 birr or (10526 USD) in 2014 for other immovable assets and he is not much satisfied with compensation given to him comparing with current market value. He is criticizing consultation mechanism employed, grievances handling procedures. He has been severing after leaved their original place without any facilitated option. There were no skill training for him and his family on how to lead his future life. He witness that there is no mechanism deployed by the government for sustainable livelihood. His sons and daughters are still in search of constant job. He is very much concerned about the future of his and his family life. He believes that local communities are not yet benefited for investment projects as expected and promised.

Moreover, in all of the interviews and focus group discussions conducted with the people, their response indicates that all of them had lost their source of income which was based on farming. As a result of this, the displacees had faced serious challenges to find and engage in other income generating activities since they lost their source of income based on farming. The fact that all the displacees of the investment projects had lost their source of income in the displacement and faced huge challenge to restore their source of income by engaging in another activity.

The following photo was taken during field observation by the researcher to identify investment related challenges in the town administration. It shows that although some investors have implemented their projects and the local communities are started to benefit from those investments in a direct or indirect ways, but numbers of projects like shown in photo below started in 2011, it is about eight years old has laid to failed to use the allotted land in spite of the fact that the developers are obliged to operate and make the local people, themselves and government beneficiaries.

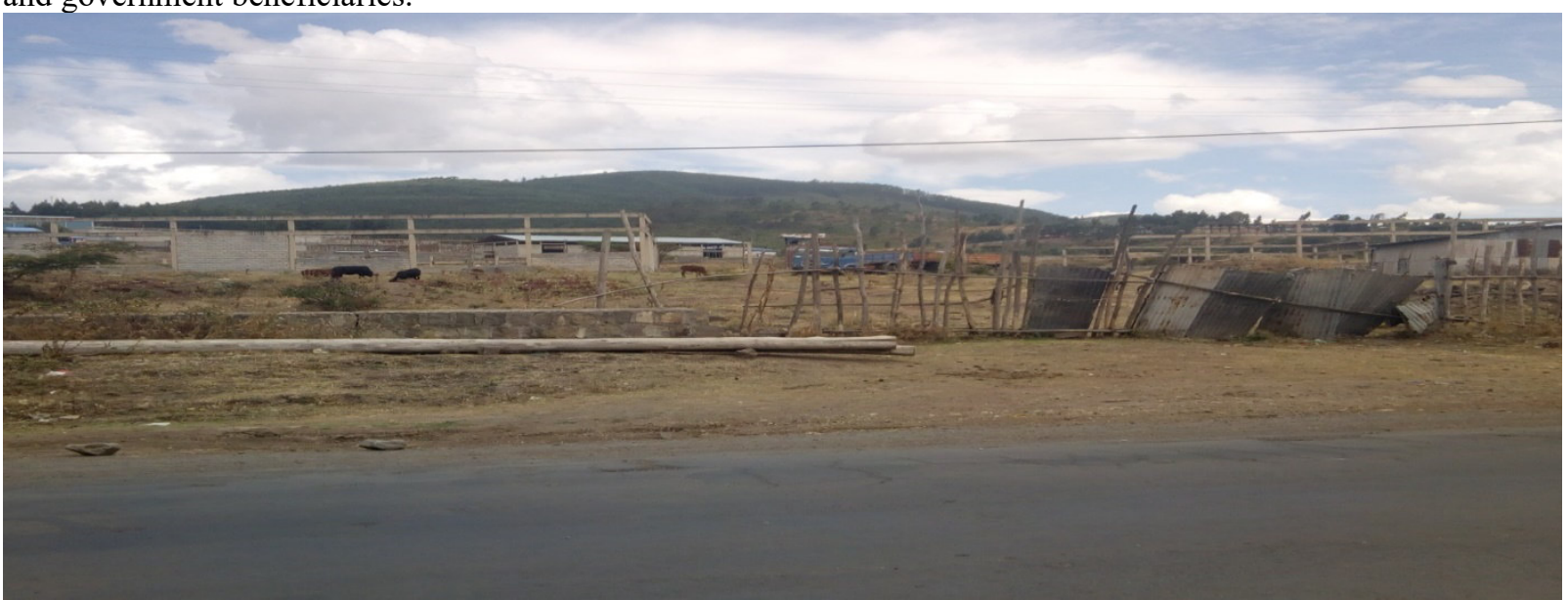

Figure 9: Land taken for investment and simply fended for eight years without expected purpose (Source: Photo taken during field observation on May, 13, 2019).

Displacement tend have negative impacts on livelihood and employment of affected people. With this regard, one participant of focus group discussion with local people addressed how he come to hear for the first time that his land was going to be used for development purpose as follows;

In the beginning, a woman in my neighbor came to my home and told me that we are going to be displaced. I was very shocked and I asked her how she came to know about. She told me that she heard from government officials of the town. After this, we spent more than two months worrying about the fate of our children after displacement without getting any tangible information. Finally the government officials called us for a meeting and informed us we will be displaced within less than three months.

(Source: Interview, April, 27, 2019, Walete). 
This show that the time given for the displacees is not enough even if decision was made by concerned government bodies. This fact is also an indication of absence of the displacees participation in the decision making process regarding an issue which would have a deep effect on their life. What the participant indicated in his response "we spent more than two months worrying about the fate of our children after displacement" which could panic the displacees and affect their efforts for advance planning about their life after the displacement.

Most of the people have become landless and homeless. In many cases, they have lost their farmland and cannot grow their own food. Furthermore, they have to spend a lot of money to build new houses without proper compensation from the state. This displacement has dismantled the livelihoods of the community. There are also individuals have not received cash compensation. Participant of focus group discussion with displaced people informed me that these individuals have tried to submit the complaint to related authorities at both local and national levels to give their land back or at least to grant them a new suitable land but there is no positive response until this data collected. There were once offered an alternative land but it is located in remote area, far distant to places of employment and facilities such as school, road and other social services.

\section{Labor Exploitation}

Most locals, according to the data obtained from focus group discussion, are employed as daily manual labourers and suffer problems related to the problem of their wages including not being paid on time. No local community member has been involved in the management or administration or technical work of the companies. They imported managers from their country and Addis Ababa.

Interviewed employees revealed that they worked overtime with 5 ETB per hour. However, the daily working hours of the country set on the Labor Proclamation was eight hours. But, employees work more than 12 hours per day including the weekend, excluding Sunday without adequate payment for overtime. Basically overtime is not necessarily problematic if it is not excessive; workers are compensated appropriately and it is chosen freely. However, in most of the cases in investment projects of Sebeta town, it is not voluntary and that workers are not given the opportunity to refuse in accordance with their rights.

Even if the payment is vary across companies, employees monthly salary did not exceed 2000.00 ETB. In response to this, employees frequently reported to town Administration Labor and Social Affairs to deal with different companies on the matter of wages of employees, but none of them negotiated the case. The office of Labor and Social Affairs confirmed the case on investment forum held in Sebeta town in May 14, 2019. I attended the forum and one of its main objectives was to identify investment related problems. Among these problems, violation of the rights of their workers as well as lack of safety among factories is one.

For instance, Yes Water Factory which is found in 02 (Alemgena) kebele. It is a factory that grievances break out over following removal of 89 factory's workers without tangible reason as members of removed workers have been interviewed. There is no money they compensated. However, the managerial staff member of the company blamed this case and informed me that the removals of these workers were related with disciple rather than something else. The case took one year in court.

Additionally, as a data obtained from an interview with one of the workers service Driver of Ayka Addis Textile and Investment Company was summarized as follows:

My salary is 1200 Ethiopian Birr per month. This was even not enough to feed my family. I have three children. Hence, this birr is not sufficient and left from school fees. My land was taken for investment purpose. The last option is to withdraw the job and search another with bring adequate salary

(Source: Interview May 1, 2019, Alemgena).

In the same manner, another, informant from youth also expressed his opinion during interview as follows: I did not see any better benefit the investment project brought to our community than before. Some of the displacees are employed in the company but it is very low level jobs like security guard and janitor. These people were well to do farmers before the displacement. But currently they are working as security guard and janitor earning small amount of salaries.

(Source Interview, May 12, 2019, Furi Gaara Bollo).

This above stated ideas implies that the livelihood of local displaced farmers were better before displacement. Because displaced farmers were more familiar in farming than any other jobs in the company.

\section{Cause of Disability}

In most studies, abrasions, cuts, burns, puncture and fracture were the common injury types among manufacturing industrial works (Adrew et al, 2011). According to data obtained from focus group discussion with workers of companies, several manufacturing did not give proper training for new employees on the operation of different machines. An accident caused by machine is common in factories. Electric shock is also another cause of disability in several factories. Hence, leg and hand/finger are injured commonly with these causative conditions. As a result of these factors causing incidents in different investment projects, disability is suffering the employees of some companies. The causes of disability in industries have been attributed to many 
factors. These are lack of training, heavy chemicals, working position standing, working position sitting, guarding on machinery, working more than expected time are few. One participant of my interview stated her ideas as follows;

My disability forced me of the chance to participate in begging. My hand was cut by machine in the factory. There was no any training for new employees I took before operating the machine. This made me disable. The factory paid me 29,600 birr as compensation three years ago. I have no birr now. Now, I am sitting here and on begging.

(Source: Interview, April, 17, 2019, Kerabu).

This response show that the occurrence of accident were attributed to lack of knowledge in what employees do during different process of production and basic training on machines before start. Hence, new employees should be trained because the more they know is the more careful they are.

\section{Local People's Perception of Investment}

The second objective of the study was intended to identify the local people perception/attitude towards investment. Accordingly, the attitude of the people was partially negative. I gave due attention to the people response in interviews, case study and focus group discussions conducted toward investment. I have also asked the participants direct questions intended to elaborate their attitude towards the investment.

\section{Reactions and Actions of the Affected People}

The affected communities are not directly consulted and as well as putting them as decision makers who determine the fate of the investment projects rather than focused only on clarifying plans and explaining the potential benefits to the communities Also, the distribution of compensation money to the affected communities was mismanaged. There are stills persons who have yet to receive their compensation money. Sebeta town administration admits that there have been some management problems in the disbursement compensation money but appears that no action has been taken to remedy them. This unresolved issue factors into the disappointment felt by the affected.

The top to down implementation approach followed did not give them a room by which they could entertain and meet the demands of the displacees. However, even if the farmers were under high pressure, they were resisting until the last hour of the displacement. With this regard, an informant who was engaged in an interview indicated his experience as stated below:

I was in my residence until the last day when the bulldozer/excavator came to my compound and started demolishing the houses. 'Bakakkaa bonaa natti ta'e, waanan godhun wallaale' (it looks me like a winter thunder, unable to do anything). I could not transport my movable resources I had in the compound. I wanted to die in my compound than leaving aside these resources without getting proper compensation. When the bull dozer was demolishing my house, I was sitting on the ground and crying bitterly. My wife fortified me a lot and I finally decided to leave the place before engaging in further dispute with the authorities.

(Source: Interview, April, 9, 2019, Dima).

The response of the above informant shows that the displacees' strong attachment toward their land their former places of residence and negative feeling the displacees have. On the other hand, absence of official information was the cause for what the informant indicated.

Though job creations, enhancement of work culture and technology transfer are seen as positive outcome of the investment, there is a tension between local people and investors. The current tension between the people and the investors is the consequences of the failure to conduct environmental impact assessments before leasing the land to the company. There was no strong sense of neighborhood between investors and people of Sebeta town. However, there are also factories working with local people and serve the surrounding community through various services like supplying water and technology transfer. The government officials confirmed that the certain companies have problems with the locals in terms of its failure to respect the rule, regulation and respect the values of the community.

\section{Amma Eessa Dhaabbanna? Where we live now?}

In Sebeta town, the contemporary land struggles are generally understood and assumed to be struggles against dispossession. Significant numbers of them were completely dispossessed, others were displaced and forced to migrate to fragile setting.

The state owns all land whereas people have only the right to use. For this reason, people have no say over land give for investment and hence the government can transfer any land it wishes to investors. The concerned government's local officials had told the local people, the benefits to be gained from the company after expropriation of land was completed. Though, displaced people were not happy with the transfer of their land to the investor. 
This in turn makes local communities voiceless because the ultimate power of deciding on the fate of investment land vests on authorities. Consequently, these communities could see their livelihoods hampered when land is transferred to investors at the expense of their interests.

The casual factor for their displacement is deliberate that the area is identified as potential and conducive are for development projects. Though, their displacement was spontaneous and unplanned, these displaced people have an understanding that the purpose of their displacement is not for bad but for good which is development. However, any displaced people from their residing area whether voluntarily or involuntarily for the cause of development, should have the right to be settled in areas of friendly environment which is clean and healthy and also have right to compensation and resettlement with the provision of different government support to lead their livelihood. This fact is evidenced by Constitution of Federal Democratic Republic of Ethiopia (1995) article 44 as per the following;

Environmental Rights, all persons have the right to a clean and healthy environment. All persons who have been displaced or whose livelihoods have been adversely affected as a result of State programmes have the right to commensurate monetary or alternative means of compensation, including relocation with adequate state assistance (FDRE, 1995).

Oromo people have special attachment to their land. The land is beyond economic value; possession of land is a source of pride and dignity in the society. As Teshome (2014) stated, Oromo people always use two terms in their daily communication. These are 'Waaqa' (God) and 'Lafa' (land). During my interview, many of displaced peoples use the expression that "Waaqa fi lafatu beeka keenya" (God and land know our future) to express the difficulty they live in. "Koo kana Waaqa fi lafatti kenne" (I gave it to God and land) to express their honesty and gratitude. "Lafti jiraa keenyas du'aa keenyas ni baata" (land hold our alive and dead).

Moreover, in order to proof what someone has told, he/she swears by dual terms of 'Waaqa fi lafa' (God and land). If he/she swears by the name of 'Waaqa fi lafa' (God and land), no one doubts the person's truth. If he/she hidden the truth, it believed that he/she is commit to a sin. Informants also express that 'lafti haadha' (land is mother) and 'lafti lafee keenya' (land is our bone). These expressions imply that land is considered as the second highest respect next to 'Waaqa' (God) in people's value. Therefore, losing land in the area implies breaking the people's usual way of life.

\section{Land Compensation and Local People Grievances}

As Vhugen (2012) stated in his article, in Ethiopia, land rights holders usually do not receive adequate compensation for land transferred to investors. Throughout my data collection, none of my informants reported that they were satisfied by the rate and amount of compensation. Addition to dissatisfaction with the amount of compensation, this was also a serious of awareness in managing and properly utilizing the cash compensation they received. Receiving compensation had appeared with its own challenges. The informants complain that the cash compensation was not only sufficient but does not stay longer, because lack of awareness in financial management is also a serious impact on the people way of using the compensation. Informants told me that nobody had advised them to properly use the money they received. There were people who have already eaten up all the compensation and became poor. They (concerned government body) do not care if someone uses the money as he/she wishes. I also understood this fact in the group discussion with the workers in the municipality where they admitted that training was not at all offered for displaced people on how to manage their compensation they received.

According to data collected through interview with one of informant among displaced people, many of relocated households for the sake of investment have been left on the bare land without direct access to public road and connection to water, electricity, sanitation and other services. Additionally, the new site is far away from schools and livelihood opportunities. One participant of my interview told me his ideas as follows;

We joined masses of gatherings. However, we were helped nothing out of the gatherings. We were going to such meetings simply to hear the officials' warning since they were not taking complains we were making. The officials were constantly urging us to leave the site within short period of time and giving warnings to those displacees who were protesting against the idea.

(Source: Interview, April, 21, 2019, Dima).

The above response of the informant indicates that such kinds of meetings that the government officials and the displacees were having regarding the displacement process was not fruitful, because the officials were calling the meetings only to displace the locals and to establish development project on their land, whereas the displacees were making complaints against the displacement. Since there was not exchange of ideas in the discussion rather than manifesting two conflicting interests, the participants of the meeting and the government officials could not reach on consensus. There was extreme pressure by the government officials to make the displacees leave the site within short period of time.

During the interview, a 41 years old woman told me about compensation as follows;

Our family resisted against displacement without sufficient compensation. On that day, my husband 
was beaten by police and imprisoned for three month. The government taken out our land and gave to investors. Hence, I cannot sustain our life. My children drop out their school and today all are daily laborers. After we lost our land, we became hopeless and depressed. Even my husband committed suicide because of this reason.

(Source: Interview, May 8, 2019, Furi).

The response of the key informant indicates that the displacement process did not take place in a peaceful manner. They were not willing to provide their land for the intended project. The displacees were even engaged in violence due to lack of proper response from the government officials. In interviews with displaced people, two themes emerged that describe the companies-local relations in the context of investment in Sebeta town: (1) a lack of respect was shown to the peoples; and (2) certain companies adversely affected the ecological balance of the peoples' natural environment.

Another participant also expressed his anger towards the government officials who were responsible for undertaking the displacement by mentioning violation of rights they committed as follows;

Even if it is your right to ask for fair compensation when there is unfair compensation, the government officials would label you as organizer of anti-development ideology for doing so. For your shock, there were detained displacees for days simply for complaining against unfair compensation. It is very irritating to be mistreated for simply asking for your rights.

(Source: Interview, May, 14, 2019, Sebeta).

The above response of the informant indicates that one of the factors for the development of negative relationship between the displacees and the local government official was the wrong methods the officials followed to handle the displacees' complain against the unfair compensation. The officials were intimidating the displacees as they were antidevelopment when the displacees claimed for fair compensations.

\section{Compensation Scheme}

In return to the lost land and residential spaces of Sebeta inhabitants due to the investment endeavors, government has adopted compensation payment mechanism to restore inhabitant's livelihood and residential spaces. The FDRE constitution proclamation No. 455/2005 expropriation of landholdings for public purposes and payment of compensation proclamation define compensation as a "payment to be made in cash or in kind or in both to a person for his property situated on his expropriated landholding." Similarly, in Sebeta, compensation is made either in terms of cash-for-land or land-for-land reparation mechanisms. Regarding the amount of the compensation payment I faced a lack of reliable data from the town administration. According to them, it is because there is a gap in recording a reliable data during the different administrative units. Nonetheless, the land administration office expert confirmed that estimation of land compensation in the town is different in each year since the town's establishment.

As to my informant in Sebeta, there is a highly corrupt administration unit in different time since the town established. For instance, they noted that inhabitants who are relatives of government official gained much better payment than other inhabitants on the same size landholdings. The estimation of cash compensation is not involved displace people. Having said the above, the question which should be emphasized is that how the locals are using the compensation payment?

Data collected shows that inhabitants use the compensation to build houses to rent, bought carts and cars, start trading under Micro and Small Enterprises, rent land and engaged in farming, others kept their money at banks and others finished in improper way due to lack of training. The different cases of inhabitants indicated that there is a relatively success and a failure in diversifying their livelihood using compensation payment although many of them find acclimatizing the new livelihood way difficult.

One of my informant from sebeta town land administration office during interview and who requested anonymity stated that, the issue here is land that is being taken away from farmers to given out to potential investors. While this might be a noble idea in terms of attracting investors and enhance development, its administration has always controversial. For the sake of development, federal and regional governments in the country take plots of land away from the farmers with very few cash compensation and transferred it to investors with high amount of money. This shows that the town has huge potential for investment. But when looking at the situation, there is the system allows officials (small/big), ways to use their position to advance their personal gains and satisfy their selfish motives by the name of investment.

By the same manner, a 57 years old man who is resident of Sebeta town in kebele called Dima; he has 8 families' members. He lost his landholding equivalent to 2 hectares because of floriculture six years ago has expressed his discontent as follows;

I was paid 120,000 Birr or (4210.5 USD). I spent some amount of money to celebrate the wedding of my two daughters. I spent the remaining amount for food and other daily basic needs. Now I have left with nothing while my family is displaced. My sons have been migrated to Addis Ababa and work on their labor while my daughters have dropped out from school and work as house maids. 
(Source: Interview, April 16, 2019, Dima).

The situation of the affected people shows that the expropriation of the landholdings has caused food insecurity. The mismanagement of money paid caused displacement of the family and forced them to lead a devastating life.

\section{Expectation and Realities}

According to data obtained through interview, management staffs of some companies replied that the companies tried to meet the demand of the local people by expanding their investment services, though it failed to do so because of insufficient foreign exchange and instability in the region.

Some companies provide clean drinking water for locals (Best plastic Factory), built houses for poorer households (Yes Water Factory). Some flower farms give water and electricity freely for the surrounding community of investment site. All the rest of the promises were left without implementation up to the date of the data collected. Hence, the government just gave moral obligation to the companies to improve the infrastructure of the local community to attract the attention of local dwellers for their investment. Therefore, it was set as the investor's moral obligation to the promised infrastructural development for the people of the study area.

\section{The False Promises}

Prior to displacement of people, the displacees were called meeting several times to discuss about compensation and services to be fulfilled and livelihood rebuilding strategies to be conducted to reestablish livelihoods of displaced people. Consequently, the displacees were promised to have necessary social services and means of income than before. The promised services include electricity, water, road, and organizing displacees in varies micro level income earning activities. One informant during interview with displaced people also indicated that none of the promised services made by government were fulfilled. She told me as follows;

Before displacement, the officials told us that all the required services will be fulfilled in the coming few months and then we will have better access to the services than we had then. However, they are kidding us like a child. After relocation let alone fulfilling the promises; it took them eight months to give us land for house construction. After that time we asked them about the services and they replied us the participation and money contribution of displacees is mandatory. Our patience becomes peak level to wait the government and investors for necessary social services. Then, finally, we decided to protest the government and remove investors from our land in 2014. Because of this reason, many factories were burnt. Later, the government and investors collaboratively free electricity, water to us. These social services are not what they gave us as promised than what we got by percolating our blood.

(Source: Interview, May, 7, 2019, Daleti).

The above response shows that how much the life after displacement is challenging because of lack of social services. Also, it shows the consequence of false promises of the government officials and responding the question of the people in improper way.

\section{Coping Strategies of the Local People}

This section deals with the fourth objective of the study which was intended to identify the coping strategies employed by the affected people to overcome with the challenges of the investment.

I have observed that investment has tremendous impacts on local livelihoods. In response to these impacts, people have certain coping strategies to overcome the impacts. Some livelihoods diversified their livelihood strategies while others strengthened existing ones. For instance some farmers who depended on the land for their livelihood prior to the land transfer have now changed their land uses or even their occupation.

The establishment of several investment projects resulted in the alteration of the households' modes of life. The affected households have totally or partially lost the assets on which their livelihoods were mainly dependent on. The affected households have totally or partially lost the assets on which their livelihoods were mainly dependent on. Moreover, their rich indigenous knowledge, gained through life long years of experience, is no longer viable to fully sustain their livelihoods. Necessity, which is an involuntary approach, has forced them to adopt new livelihood strategies through which they can sustain their livelihoods and fulfill their household requirements. In this respect, the livelihood strategies adopted by the displaced households in the study area can be characterized as survival or necessity rather than having a choice from a number of alternatives.

As I have seen in the study area, the expansion of investment activities has tremendous impacts on the local people's livelihoods. To overcome these challenges, people have adopted some coping strategies in their life to survive. For example, some local people, who depended on the land for their livelihood before the land was transferred to investor, have now changed their occupation. The findings of interview, focus group discussions, case study and observation revealed that the displaced households faced lots of challenges that investment brought.

According to in-depth interview and focus group discussions, landless and jobless households whose basic 
livelihood assets were taken away are forced to engage in available nonfarm activities. Household‘s members engage in available income earning activities such as guard, daily labor, trade (producing local liquor (Areke) and engage in liquor shop on home base, preparing food), broker and moving to another places in search of better life. The section below presents the coping strategies used by the local people in order to overcome the challenges they faced from the expropriation of land to investors.

\section{Daily Labor}

With the thriving of various manufacturing industries and investment projects, various types of job opportunities are created for the displaced households and local people in general. Among all the activities the displaced households used as coping strategies, daily laborer was an activity widely used irrespective of the different demographic factors the families had. Most of the displaced considered daily laborer work as coping mechanism. It is a strategy employed by the displaced household members to fulfill their financial requirements. The majority of the affected individuals employed in daily labor were engaged in works that required no special skills. However, very few individuals who could at least read were employed as guards in the companies. This job type is generally viewed as a better job type by the affected and is thus preferred. As information gathered indicates, to date, trained jobs, wage labor based works and other employment likelihoods are vacant for the inhabitants, thereby inhabitants are involving in those careers. Data collected reveals that conspicuously job opportunities are created more often for the youth of the area than any other age groups.

\section{Self-employment in Informal Sector}

During the focus group discussions, it was found that the self-employed informal activities mainly consisted of making and selling local alcohol drinks. Some of the interviewed individuals also reported to collect and sell fire wood and cans. Some women were mainly engaged in the self-employed informal activities.

\section{Conclusion and Recommendations \\ Conclusion}

It is revealed that the main purpose of this academic text is to examine the challenges and opportunities of investment to people of Sebeta town. To this end, sustainable development model and basic need approach have employed to interpret the data. As it is indicated in the literature, debate on opponents and proponents of investment particularly for developing countries like Ethiopia, some challenges and opportunities of investment, experience of some selected countries and policy and legal frameworks related with investment were analyzed accordingly.

In case of Sebeta town, investment brought several opportunities to the people of the town. Such as job creation, technology transfer and various social services like light and water. However, there are hindering challenges related to it. Accordingly, the study identified that land expropriation, environmental pollution, labor exploitation, instability, loss of livelihood and involuntary displacement with inadequate compensation, escalation of corruption and injustices were identified challenges. These challenges emanated from several reasons. Most of investment projects did not consult with people and promised community development have not been realized. The establishment of several investment projects resulted in the alteration of the household's modes of life. The affected households have totally or partially lost the assets on which their livelihoods were mainly depend on. In order to overcome these above mentioned challenges, the livelihood adopted by the affected people characterized as survival or necessity rather than having a choice from a number of alternatives. Hence, people have adopted some strategies like daily labor, self-employed informal activities.

In general, this study discovered the investment has brought more costs than benefit. Hence, in order to minimize these problems, investors dealing with people directly and both government and investors ensure investment will have a positive impact on local livelihoods.

\section{Recommendations}

Based on the findings of this study, the following are recommended for the government and investors as well.

$>$ Government should formulate integrated guidelines to benefit local communities as well through having share in companies rather than displacing with compensation.

$>$ In the process of land allocation to the investors' local peoples should be consulted and even participated in deal.

$>$ Throughout the project, the project managers should deal directly with affected communities, rather than through a middleman or government agency. Thus, participation of local people in the investment is key elements to be successful.

$>$ Special attention should be given to ensuring that the legal framework adequately protects the rights of local people.

$>$ Investment Projects of the town are unevenly distributed. For instance, there are 4 GM-Furniture, 
seventy plastic factories established at different sites. Therefore, it is better to relocate such like industries to one area. Accordingly, Industry zone should be proposed, considering location of resident and river streams.

$>$ Investor (s) should understand and respect local conditions, i.e. culture of people where they invest.

\section{References}

Abbink, Jon (2011). 'Land to the Foreigners': Economic, Legal, and Socio-cultural Aspects of New Land Acquisition Schemes in Ethiopia, Journal of Contemporary African Studies, 29:4, 513-535.

Adrew, Zewdie; Engdaw, Dagnew; Tadesse, Takele (2011). Determinants of Occupational Injury: A Case Control Study among Textile Factory Workers in Amhara Regional State, Ethiopia: Journal of Tropical Medicine: Volume 2011.

Andersen, Per Pinstrup; Robertson, Beth (2010). Global Land Acquisition: Neo-colonialism or Development Opportunity? Springer Science + Business Media B.V. \& International Society for Plant Pathology. Pp 271283.

Atkure, Defar; Ahmed, Ali (2013). Occupational Induced Health Problems in Floriculture Workers in Sebeta and Surrounding Areas, West Shewa, Oromia, Ethiopia. Ethiop. J. Health Dev. 27(1).

Azeb, Degife (2017). The Intricacies of Large Scale Agricultural Investment in Gambella Region, Ethiopia: Paper Prepared for Presentation at the "World Bank Conference on Land and Poverty" The World Bank Washington Dc, March 20-24, 2017: Ludwig Maximilian University of Munich (LMU): Germany.

Azeb W. Degife, Wolfram, Mauser (2017). Socio-economic and Environmental Impacts of Large-Scale Agricultural Investment in Gambella Region, Ethiopia: Journal of US-China Public Administration, April 2017, Vol. 14, No. 4, 183-197: Ludwig Maximilian University of Munich (LMU), Munich, Germany

Dejene, Adugna (2016). Impact of Urban Sprawl on Farm Lands: The Case of Sebeta town (MA Thesis): Addis Ababa University: Ethiopia.

Dejene, Nemomsa (2014). Land Grab in Ethiopia: The Case of Karuturi Agro Products Plc. In Bako Tibe, Oromia (MA Thesis): Trondheim, Norway.

Desalegn, Rahmato (2011). Land to Investors: Large-Scale Land Transfers in Ethiopia: Forum for Social Studies, Addis Ababa: Ethiopia.

Ermias, Abera (2009). Urban Development-Induced Displacement: Prospective and Challenges of Real Estate Development on the Livelihoods of Rural Communities: The Case of LegaTafo Lega Dadi (MA theses): Addis Ababa University: Ethiopia.

Ermias, Tamiru (2013). A Study on Impacts of Investment Policy of Ethiopia on Rural Employment with Particular Reference to Floriculture Industry: Addis Ababa, Ethiopia.

Feyera, Abdissa (2005). Urban Expansion and the Livelihood of the Peri-Urban Agricultural Community: The Case of Addis Ababa (Unpublished MA Thesis): Addis Ababa University: Ethiopia.

Geary, K. (2012). Our land, our lives: Time out on the global land rush: Oxfam policy and Practice: Private sector, 9(2), 1-26.

Getnet, A. (2012). Rural Land Policy, Rural Transformation and Recent Trends in Large-scale Rural Land Acquisitions in Ethiopia: European Report on Development.

Getu, M. (2009), Mizan Law Rev: Ethiopian Floriculture and its Impact on the Environment, vol.3. http://www.ajol.info/index.php/mlriarticle/viewFile/54011/42554 accessed 25/10/2018.

Gray, D. (2004). Doing Research in the Real World. London: SAGE Publications.

Hodbod Jennifer, Stevenson Edward, Gregory Akall, Akuja Thomas, Angelei Ikal, Buffavand Lucie, Derbyshire Samuel, Elias Alemu, Eulenberger Immo, Gownaris Natasha, Kamski Benedikt, Kurewa Abdikadir, Michael Lokuruka, Mercy Fekadu, Okenwa Doris, Rodgers Cory, Tebbs Emma (2019). Social-ecological Change in the Omo-Turkana basin: A synthesis of Current Developments: Kungl.Veternskaps Academien, The Royal Swedish Academy of Sciences,

Isabelle, Gebretensaye (2015). Chinese Foreign Direct Investments in Ethiopia-The Potential for Development or a Development Trap? Nationalekonomiska Institutionen: University of Lund: Sweden.

Kaarhus Randi, Haug Ruth, Hella Joseph P., and Makindara Jeremia R. (2010). Agro-Investment in AfricaImpact on Land and Livelihoods in Mozambique and Tanzania: Noragric Report No. 53: Norwegian University of Life Sciences.

Kuma, Daba (2012). Performance, Challenges and Prospects of Private Investment in Sebeta City Administration: Addis Ababa University (MA Thesis): Ethiopia.

Lay, J. \& Nolte, K. (2011). Nuer, "Land grab in Afrika?” GIGA Focus, 1. Hamburg.

Mckeown, R., Hopkins, C.A., Rizzi, R. and Chrystalbridg, M. (2006). Education for Sustainable Development tool kit: Learning and training took, No.1. UNESCO: Paris.

Mesfin, Araya (2013). Effects of Large-Scale Agricultural Investments on Smallholder Farming in Sub-Saharan Africa (Case Study: Ethiopia): Lund University. 
Oakland Institute (2011). Understanding Land Investment Deals in Africa. Country report: Ethiopia. USA: The Oakland Instiute.

OUPI (2007). Report of Structure Plan of Sebeta Town, Finfinne: Ethiopia.

OUPI (2018). Sebeta town Structure Plan Revision: Sebeta town History and Heritage Study: Finfinne: Ethiopia. Seers, D. (1970). The Meaning of Development: New York: Agricultural Development Council Reprint.

Simon, K. (2001). Displaced Workers and Employer-Provided Health Insurance: Evidence of a wage/Fringe Benefit Tradeoff: International journal of health care Finance and Economics 1: pp. 249-271.

Solow, R (1956). A Contribution to the Theory of Economic Growth, Quarterly Journal of Economics, Vol. 70, pp. 65-94.

Songwe, Vera and Deininger, Klaus (2009). Foreign Investment in Agricultural Production: Opportunities and Challenges: Agriculture and Rural Development: Land Policy and Administration: Issue 45: Washington DC.

Streeten, P. (1981). First Things First: Meeting Basic Nee\& in Developing Countries: New York: Oxford university Press.

Teshome, Emana (2014). The Transforming Power of Urbanization: Changes and Uncertainties among the Farming Community in Laga Xafo-Laga Dadhi Town, Ethiopia (PhD Dissertation): Addis Ababa University: Ethiopia.

Vhugen, Darryl (2012). Large-Scale Commercial Investments in Land: Seeking to Secure Land Tenure and Improve Livelihoods: Haramaya University College of Law's Environmental Policy Center and Social Justice Center: Ethiopia.

World Bank (2010). The Global Land Rush. Can it Yield Sustainable and Equitable benefits? Washington DC. World Bank. 8 September. 